\title{
Role of Nociceptor $\alpha$ CaMKII in Transition from Acute to Chronic Pain (Hyperalgesic Priming) in Male and Female Rats
}

\author{
Luiz F. Ferrari, Oliver Bogen, and Jon D. Levine \\ Departments of Medicine and Oral Surgery and Division of Neuroscience, University of California at San Francisco, San Francisco, California 94143
}

\begin{abstract}
We have previously shown that activation of protein kinase $\mathrm{C} \varepsilon(\mathrm{PKC} \varepsilon)$ in male rats induces a chronic, long-lasting change in nociceptors such that a subsequent exposure to proinflammatory mediators produces markedly prolonged mechanical hyperalgesia. This neuroplastic change, hyperalgesic priming, is dependent on activation of cytoplasmic polyadenylation element-binding protein (CPEB), downstream of PKC $\varepsilon$, and consequent translation of mRNAs in the peripheral terminal of the nociceptor. Since $\alpha$ calmodulin-dependent protein kinase II ( $\alpha$ CaMKII), a molecule implicated in neuroplasticity, is a target of CPEB and can also affect CPEB function, we investigated its role in the transition from acute to chronic pain. Priming induced by direct activation of PKC $\varepsilon$ can be prevented by inhibition of $\alpha$ CaMKII. In addition, direct activation of $\alpha$ CaMKII induces priming, which was not prevented by pretreatment with PKC $\varepsilon$ antisense, suggesting that $\alpha \mathrm{CaMKII}$ is downstream of PKC $\varepsilon$ in the induction of priming. Activation of ryanodine receptors (RyRs), which can lead to activation of $\alpha$ CaMKII, also induced priming, in a calcium- and $\alpha$ CaMKII-dependent manner. Similarly, inhibition of the RyR and a calcium buffer prevented induction of priming by PKC $\varepsilon$. Unlike activation of PKC $\varepsilon$, ryanodine and $\alpha$ CaMKII induced priming in female as well as male rats. Our results demonstrate a contribution of $\alpha$ CaMKII to induction of hyperalgesic priming, a phenomenon implicated in the transition from acute to chronic pain.
\end{abstract}

\section{Introduction}

The inability to reverse chronic pain is due in part to lack of knowledge of its underlying mechanism. We have demonstrated that inflammatory mediators that activate protein kinase $\mathrm{C} \varepsilon$ $(\mathrm{PKC} \varepsilon)$ can produce a neuroplastic change in isolectin $\mathrm{B}_{4^{-}}$ positive $\left[\mathrm{IB}_{4}(+)\right]$ nociceptors, referred to as hyperalgesic priming, such that subsequent exposure to a pronociceptive inflammatory mediator [e.g., prostaglandin $\mathrm{E}_{2}\left(\mathrm{PGE}_{2}\right)$ ] produces enhanced and markedly prolonged mechanical hyperalgesia (Aley et al., 2000; Parada et al., 2003a, 2005; Reichling and Levine, 2009; Joseph and Levine, 2010). However, once priming is established, although attenuation of $\mathrm{PKC} \varepsilon$ can transiently abrogate its expression, i.e., inhibit the prolongation of $\mathrm{PGE}_{2}$ hyperalgesia, it cannot permanently reverse the underlying neuroplastic change in the nociceptor and terminate the primed condition. To evaluate the mechanisms involved in the induction of priming downstream of $\mathrm{PKC} \varepsilon$, in subsequent experiments we demonstrated that downregulation of cytoplasmic polyadenylation elementbinding protein (CPEB), an RNA-binding molecule that regulates the translation of otherwise dormant mRNAs in peripheral

Received April 29, 2013; revised May 21, 2013; accepted May 24, 2013.

Author contributions: L.F.F., O.B., and J.D.L. designed research; L.F.F. and 0.B. performed research; L.F.F. analyzed data; L.F.F., O.B., and J.D.L. wrote the paper.

This study was supported by the National Institutes of Health.

The authors declare no competing financial interests.

Correspondence should be addressed to Dr. Jon D. Levine, University of California, San Francisco, 521 Parnassus Avenue, San Francisco, CA 94143-0440. E-mail: jon.levine@ucsf.edu.

DOI:10.1523/JNEUROSCI.1785-13.2013

Copyright $\odot 2013$ the authors $\quad 0270-6474 / 13 / 3311002-10 \$ 15.00 / 0$ axons (Richter, 2007; Villalba et al., 2011) and that is a downstream target of PKC $\varepsilon$ (Bogen et al., 2012), also prevents priming (Bogen et al., 2012). In the present study, to explore pathways downstream of CPEB that underlie the induction of hyperalgesic priming, we evaluated the role of $\alpha$ calmodulin-dependent protein kinase II $(\alpha$ CaMKII), a cytoplasmic polyadenylation element-containing species of dormant mRNA (Wu et al., 1998) that is found in sensory axons (VanBerkum and Goodman, 1995; Hiruma et al., 1999; Geddis and Rehder, 2003; Gleason et al., 2003 ) and that has been implicated in neuroplasticity (Cammarota et al., 2002; Gleason et al., 2003; Yamauchi, 2005; Buard et al., 2010; Coultrap et al., 2010; Jama et al., 2011).

Another aspect of hyperalgesic priming that has remained unexplained is that production of priming by agonists for receptors that signal through $\mathrm{PKC} \varepsilon$, or by direct activation of $\mathrm{PKC} \varepsilon$, which both produce priming in male rats, does not produce priming in females (Joseph et al., 2003). Therefore, as a secondary goal of the present experiments, we tested the hypothesis that activation of hyperalgesic priming mechanisms downstream of $\mathrm{PKC} \varepsilon$ can produce priming in females as well as males.

\section{Materials and Methods}

Animals. All experiments were performed on adult male and female Sprague Dawley rats (220-400 g; Charles River Laboratories). Animals were housed, three per cage, under a $12 \mathrm{~h}$ light/dark cycle in a temperature- and humidity-controlled room in the animal care facility of the University of California at San Francisco. Food and water were available ad libitum. All nociceptive testing was done between 10:00 A.M. and 5:00 P.M., and the experimental protocols were approved by the Institutional Animal Care and Use Committee at the University of California at 
San Francisco and adhered to the National Institutes of Health Guidelines for the Care and Use of Laboratory Animals. All efforts were made to minimize the number of animals used and their suffering.

Mechanical nociceptive threshold testing. Mechanical nociceptive threshold was quantified using a Ugo Basile Analgesymeter (RandallSelitto paw-withdrawal test; Stoelting), which applies a linearly increasing mechanical force to the dorsum of the rat's hindpaw, as described previously (Randall and Selitto, 1957; Taiwo and Levine, 1989; Taiwo et al., 1989). Rats were placed in cylindrical acrylic restrainers designed to provide adequate comfort and ventilation, allow extension of the hind leg from the cylinder, and minimize restraint stress. All rats were acclimatized to the testing procedure, and testing was performed in parallel across groups. Rats were adapted to the restrainer for $1 \mathrm{~h}$ before starting each study and for $30 \mathrm{~min}$ before experimental manipulations. The nociceptive threshold was defined as the force (in grams) at which the rat withdrew its paw, and the baseline paw-pressure threshold was defined as the mean of the three readings taken before the test agents were injected. Each paw was treated as an independent measure, and each experiment was performed on a separate group of rats. Group data are presented as mean \pm SEM change from baseline mechanical nociceptive threshold.

Drugs and their administration. The following chemicals were used in this study: $\mathrm{PGE}_{2}$ (direct-acting hyperalgesic inflammatory mediator), ryanodine [a ryanodine receptor (RyR) activator], dantrolene sodium salt (an RyR inhibitor), and the intracellular calcium transport inhibitor 3,4,5-trimethoxybenzoic acid 8-(diethylamino) octyl ester (TMB-8), all from Sigma-Aldrich; $\alpha$ CaMKII recombinant (activated $\alpha$ CaMKII; New England Biolabs); the CaMKII inhibitor peptide CaM2INtide (GenScript); the PKC $\varepsilon$-specific translocation inhibitor peptide (PKC $\varepsilon-\mathrm{I})$ PKC $\varepsilon V_{1-2}$, (Johnson et al., 1996; Khasar et al., 1999) (Calbiochem); the PKC $\varepsilon$ activator $\psi \varepsilon$ RACK (Biomatik); and the protein translation inhibitors cordycepin $5^{\prime}$-triphosphate sodium salt (Sigma-Aldrich) and rapamycin (EMD Chemicals). The selection of the drug doses used in this study was based on doses determined during our previous studies (Taiwo et al., 1990; Ouseph et al., 1995; Khasar et al., 1999; Aley et al., 2000; Parada et al., 2005; Ferrari et al., 2013b).

Stock solutions of $\mathrm{PGE}_{2}$ in absolute ethanol $(1 \mu \mathrm{g} / \mu \mathrm{l})$ were diluted in $0.9 \% \mathrm{NaCl}\left(1: 50, C_{\text {final }}=0.2 \mu \mathrm{g} / \mu \mathrm{l}\right)$ immediately before injection. The ethanol concentration of the final $\mathrm{PGE}_{2}$ solution was $\sim 2 \%$, and the injection volume was $5 \mu \mathrm{l}$. Stock solutions of cordycepin $(10 \mu \mathrm{g} / \mu \mathrm{l}$, dissolved in a $1: 1$ mixture of $0.9 \% \mathrm{NaCl}$ and absolute ethanol) or rapamycin $(20 \mu \mathrm{g} / \mu \mathrm{l}$, dissolved in absolute DMSO) were further diluted in $0.9 \% \mathrm{NaCl}$ or distilled water, respectively, immediately before injection. The ethanol or DMSO concentration in the final solutions was $\sim 2 \%$.

Activation of $\alpha$ CaMKII was performed in vitro, and a dose of $25 \mathrm{ng}$ (2.5 $\mu \mathrm{l})$ of the activated $\alpha$ CaMKII was injected on the dorsum of the rat hindpaw. $\alpha$ CaMKII was diluted in $1 \times$ NEBuffer for PK (50 mm Tris$\mathrm{HCl}, 10 \mathrm{~mm} \mathrm{MgCl}_{2}, 0.1 \mathrm{~mm}$ EDTA, 2 mM DTT, 0.01\% Brij 35, pH 7.5 at $25^{\circ} \mathrm{C}$ ) supplemented with $200 \mu \mathrm{M} \mathrm{ATP}, 1.2 \mu \mathrm{M}$ calmodulin, and $2 \mathrm{~mm}$ $\mathrm{CaCl}_{2}$ and incubated for $10 \mathrm{~min}$ at $30^{\circ} \mathrm{C}$ before injection.

Drugs were administered on the dorsum of the hindpaw via a beveled 30 gauge hypodermic needle attached to a Hamilton microsyringe by a short length of polyethylene (PE-10) tubing. The administration of activated $\alpha$ CaMKII, CaM2INtide, PKC $\varepsilon$-I, $\psi \varepsilon$ RACK, ryanodine, dantrolene sodium salt, TMB-8, and the protein translation inhibitors was preceded by a hypotonic shock to facilitate cell permeability to these agents ( $2 \mu \mathrm{l}$ of distilled water, separated by a bubble of air to avoid mixing in the same syringe), to get compounds into the nerve terminal (Borle and Snowdowne, 1982; Burch and Axelrod, 1987).

Oligodeoxynucleotide antisense to PKC $\varepsilon$ and $\alpha C a M K I I$. Oligodeoxynucleotide (ODN) antisense (AS) to PKC $\varepsilon$ mRNA, shown previously to decrease PKC $\varepsilon$ in dorsal root ganglion neurons (Parada et al., 2003a) when administered intrathecally, was synthesized by Invitrogen. The ODN AS, 5' -GCCAGCTCGATCTTGCGCCC-3', was directed against a unique sequence of PKC $\varepsilon$. The ODN mismatch (MM), 5'-GCCAGCGC GATCTTTCGCCC- $3^{\prime}$, is the AS sequence with two bases (denoted in boldface) switched. A search of the EMBL and NCBI GenBank Rattus norvegicus databases identified no homologous sequences.

The ODN AS sequence for the $\alpha$-subunit of CaMKII, $5^{\prime}$ GGTAGCCATCCTGGCACT-3' (Invitrogen), was directed against a unique region of the rat mRNA sequence. The corresponding NCBI GenBank accession number and ODN position within the mRNA sequence are NM_012920 and 33-50, respectively. That this ODN AS can be used to downregulate the expression of $\alpha$ CaMKII has been shown previously (Churn et al., 2000). The ODN MM sequence 5'GGTAGCCATAAGGGCACT-3' corresponds to the AS sequence with three bases mismatched (denoted in boldface).

Before use, the ODNs were lyophilized and reconstituted in $0.9 \% \mathrm{NaCl}$ to a concentration of $2 \mu \mathrm{g} / \mu \mathrm{l}$. During each injection, rats were briefly anesthetized with $2.5 \%$ isoflurane in $95 \% \mathrm{O}_{2}$. A 30 gauge hypodermic needle was inserted into the subarachnoid space on the midline, between the L4 and L5 vertebrae. A total of $40 \mu \mathrm{g}$ of ODN in a volume of $20 \mu \mathrm{l} \mathrm{per}$ rat was slowly injected. Proper intrathecal injections were systematically confirmed by checking for a sudden flicking of the tail, a reflex that is evoked by subarachnoid space access and bolus injection (Mestre et al., 1994). This method of injecting into the intrathecal space has proven to be very accurate and reproducible, as revealed by intrathecal injections of vital dyes and radioligands such as methylene blue and $\left[{ }^{3} \mathrm{H}\right]$ morphine (Mestre et al., 1994; Bilsky et al., 1996). The animals regained consciousness $\sim 1$ min after the injection. The use of ODN AS to manipulate the expression of proteins in nociceptors, important for their role in nociceptor sensitization, is well supported by previous studies by others (Song et al., 2009; Su et al., 2011; Quanhong et al., 2012; Sun et al., 2013) as well as our group (Parada et al., 2003a; Ferrari et al., 2010, 2012; Bogen et al., 2012).

Statistics. In all experiments, the dependent variable was pawwithdrawal threshold, expressed as the percentage change from baseline. No significant difference in the mechanical nociceptive thresholds was observed before the injection of the priming stimuli ( $\psi \varepsilon$ RACK, activated $\alpha$ CaMKII, or ryanodine, depending on the experiment) and immediately before $\mathrm{PGE}_{2}$ injections (average mechanical nociceptive thresholds before priming stimuli were $118.8 \pm 0.7 \mathrm{~g}$; average mechanical nociceptive thresholds before $\mathrm{PGE}_{2}$ injections were $118.1 \pm 0.6 \mathrm{~g} ; n=170$ paws; paired Student's $t$ test, $t_{(52)}=0.7035, p=0.4849$ ). As noted in the figure legends, two-way repeated-measures ANOVA, followed by the Bonferroni's post hoc test, was performed to compare the magnitude of the hyperalgesia induced by the priming stimulus or by $\mathrm{PGE}_{2}$ injection in different conditions, and $p$ values $<0.05$ were considered statistically significant. Data are presented as mean \pm SEM.

\section{Results}

\section{$\alpha$ CaMKII inhibition prevents induction of priming}

To determine whether $\alpha$ CaMKII has a role in the induction of hyperalgesic priming, we tested whether intrathecal treatment with ODN AS to $\alpha$ CaMKII mRNA would prevent the development of $\mathrm{PKC} \varepsilon$ agonist $\psi \varepsilon \mathrm{RACK}$-induced hyperalgesic priming. Since the AS treatment does not totally knock down the expression of $\alpha$ CaMKII (Churn et al., 2000), we combined AS treatment with intradermal injection of the CaMKII inhibitor CaM2INtide, at the site of nociceptive testing, to minimize activation of $\alpha \mathrm{CaMKII}$ by PKC $\varepsilon$. We found that intrathecal treatment with $\alpha$ CaMKII AS combined with local inhibition of CaMKII prevented the development of priming induced by injection of $\psi \varepsilon$ RACK; $\mathrm{PGE}_{2}$-induced hyperalgesia, tested 1 week after the treatment with the AS plus inhibitor for CaMKII has finished (11 d after $\psi \varepsilon$ RACK injection), was significantly less at the fourth hour in the AS plus inhibitor-treated group compared with the group treated with $\alpha$ CaMKII MM ( $p<0.001$; Fig. 1$)$. This result supports the hypothesis that $\alpha$ CaMKII is important for the induction of hyperalgesic priming. In addition, a control experiment was performed to confirm the inhibitory effect of CaM2INtide against $\alpha$ CaMKII. The injection of activated $\alpha$ CaMKII (25 ng) on the dorsum of the hindpaw induced significant mechanical hyperalgesia that lasted at least 1 week. However, administration of $\alpha$ CaMKII activated in the presence of the inhibitor did not induce significant change in the mechanical 

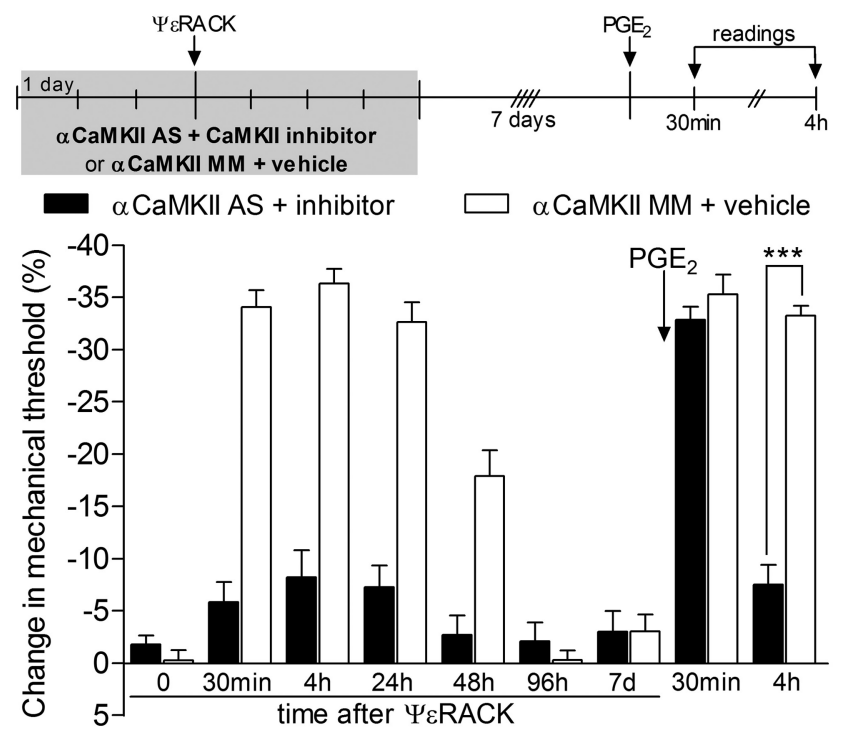

Figure 1. PKC $\varepsilon$-induced hyperalgesic priming is $\alpha$ CaMKII dependent. Rats were treated with daily intrathecal injections of ODN AS (filled bars) or mismatch (MM; open bars) for $\alpha$ CaMKII mRNA for 3 consecutive days. In addition, the CaMKII inhibitor ( $1 \mu \mathrm{g}$, filled bars) or vehicle (open bars) was injected on the dorsum of the hindpaw daily. On the third day of ODN AS plus inhibitor or MM plus vehicle treatment, $\psi \varepsilon \operatorname{RACK}(1 \mu \mathrm{g})$ was administered at the same site as the inhibitor or vehicle. Mechanical nociceptive thresholds were then evaluated by the Randall-Sellitto paw-withdrawal test 30 min and 4, 24, 48, and $96 \mathrm{~h}$ after $\psi \varepsilon$ RACK administration. The ODN plus inhibitor or vehicle treatments were continued until the return of the mechanical threshold to baseline values (on the seventh day). Repeated-measures ANOVA followed by Bonferroni's post hoc test showed significant mechanical hyperalgesia induced by injection of $\psi \varepsilon R A C K$ in both groups $\left(F_{(5,50)}=31.28 ; p<0.0001\right.$ compared with baseline thresholds). However, when both groups were compared, $\psi \varepsilon$ RACK-induced mechanical hyperalgesia was significantly attenuated in the AS plus inhibitor group $\left(F_{(1,50)}=237.8 ; p<\right.$ $0.0001)$. Seven days after the last treatment with ODN AS plus inhibitor or ODN MM plus vehicle (11 d after $\psi \varepsilon$ RACK injection), we tested for hyperalgesic priming by intradermal injection of $\mathrm{PGE}_{2}(100 \mathrm{ng}$ ) in the same site as $\psi \varepsilon$ RACK and the CaMKII inhibitor (or vehicle). Two-way repeated-measures ANOVA followed by Bonferroni's post hoc test showed that, although the mechanical hyperalgesia was not significantly different in both groups 30 min after $\mathrm{PGE}_{2}(p>$ 0.05 ), at the fourth hour a significant attenuation in the group previously treated with ODN AS plus inhibitor was observed, when compared with the MM plus vehicle-treated group $\left({ }^{* * *} p<\right.$ $0.001) . n=6$ paws per group.

threshold, showing the efficacy of the inhibitor against $\alpha$ CaMKII ( $p<0.0001$, activated $\alpha$ CaMKII group compared with the groups treated with $\alpha$ CaMKII plus inhibitor or vehicle; Fig. 2A).

\section{Activation of $\alpha$ CaMKII induces priming}

To determine whether activation of $\alpha$ CaMKII is not only necessary for the induction of but also sufficient to induce hyperalgesic priming, we injected activated $\alpha$ CaMKII (25 ng) or its vehicle intradermally on the dorsum of the hindpaw at the site of nociceptive testing. Activated $\alpha$ CaMKII, but not its vehicle, produced hyperalgesia that was prominent $4 \mathrm{~h}$ after its injection and was no longer detectable $10 \mathrm{~d}$ later (Fig. $2 \mathrm{~A}$, black bars). When the nociceptive threshold had returned to baseline, we injected $\mathrm{PGE}_{2}(100$ ng) at the site on the dorsum of the hindpaw where we had previously injected activated $\alpha$ CaMKII or its vehicle. When injected in the paw previously treated with $\alpha$ CaMKII vehicle, $\mathrm{PGE}_{2}$ induced hyperalgesia that was present $30 \mathrm{~min}$ later but was no longer detectable at $4 \mathrm{~h}$. In contrast, when $\mathrm{PGE}_{2}$ was injected in the paw previously treated with $\alpha \mathrm{CaMKII}$, robust $\mathrm{PGE}_{2}$-induced hyperalgesia was still present $4 \mathrm{~h}$ later $(p<0.001$ when both groups are compared at the fourth hour; Fig. $2 B$ ) without atten-
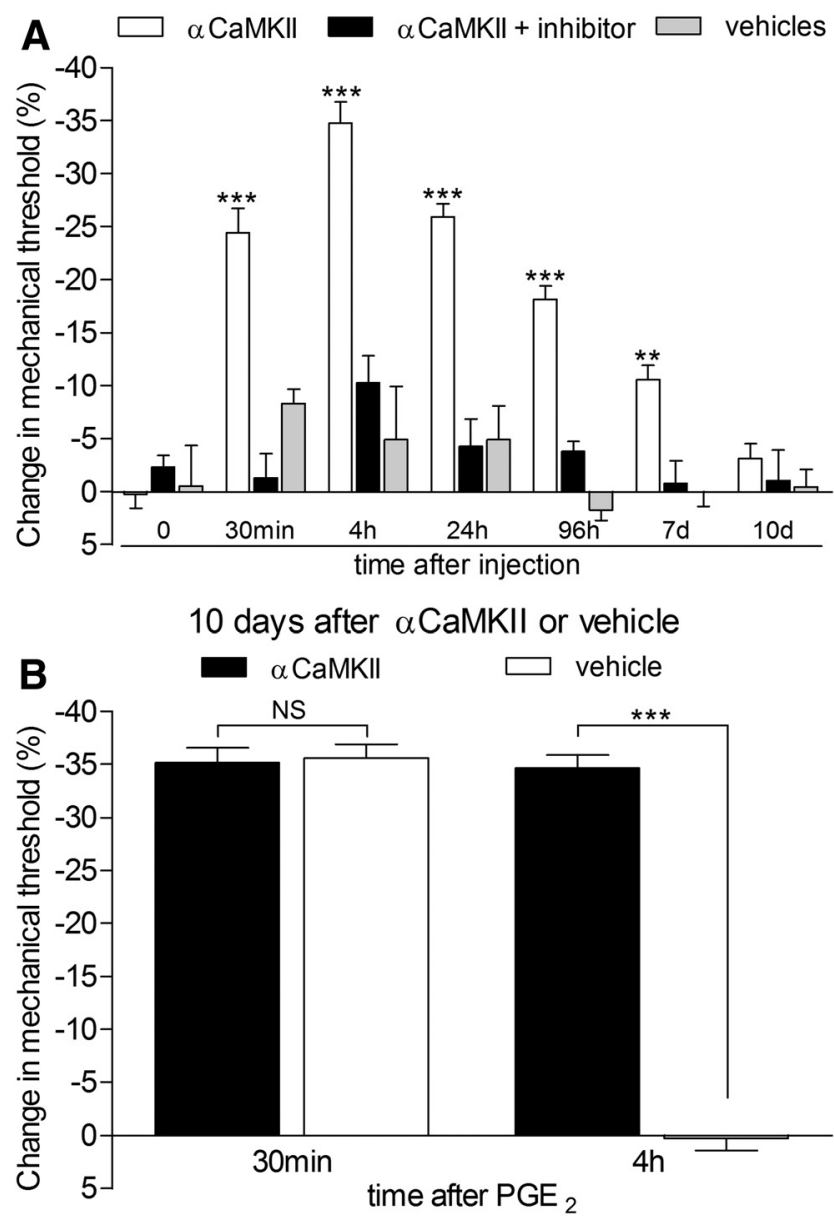

Figure 2. $\quad \alpha$ CaMKII activation induces mechanical hyperalgesia and hyperalgesic priming. $\boldsymbol{A}$ $\alpha$ CaMKII was activated in vitro in the presence (black bars) or absence (white bars) of the CaMKII inhibitor CaM2INtide. Intradermal injections, on the dorsum of the hindpaws, were performed in different groups of rats ( $25 \mathrm{ng}$ of $\alpha$ CaMKII). A control group (gray bars) received injection of the vehicles instead of $\alpha$ CaMKII. Mechanical nociceptive threshold was evaluated $30 \mathrm{~min}, 4 \mathrm{~h}$ $24 \mathrm{~h}, 96 \mathrm{~h}, 7 \mathrm{~d}$, and $10 \mathrm{~d}$ after injections. Repeated-measures ANOVA followed by Bonferroni's post hoc test showed significant mechanical hyperalgesia induced by $\alpha$ CaMKII activated in the absence of the inhibitor $\left(F_{(12,78)}=11.04 ;{ }^{* * *} p<0.0001\right.$ when compared with the groups treated with $\alpha$ CaMKII plus inhibitor or vehicles) that was still significant $7 \mathrm{~d}$ after the injection $\left({ }^{* *} p<0.01\right)$. Comparison of the groups that received the $\alpha$ CaMKII plus its inhibitor or the vehicles showed no significant statistical difference $\left(F_{(6.48)}=1.70 ; p=0.1412\right) . n=6$ paws per group. $\boldsymbol{B}$, Rats received intradermal injection of activated $\alpha$ CaMKII ( $25 \mathrm{ng}$, black bars) or its vehicle (white bars). No significant difference was observed between the mechanical thresholds before and $10 \mathrm{~d}$ after injection of $\alpha \mathrm{CaMKII}$ or vehicle, i.e., immediately before $\mathrm{PGE}_{2}$ injection (data not shown). PGE $(100 \mathrm{ng})$ was then injected at the same site as $\alpha$ CaMKII or vehicle, and the mechanical nociceptive thresholds were evaluated $30 \mathrm{~min}$ and $4 \mathrm{~h}$ later. Repeatedmeasures ANOVA followed by Bonferroni's post hoc test showed that $\mathrm{PGE}_{2}$-induced hyperalgesia was still significant at the fourth hour in the paws pretreated with $\alpha$ CaMKII, whereas in the vehicle-treated paws, the mechanical threshold had already returned to baseline at that time point $\left({ }^{* *} p<0.001\right.$, when comparing both groups at the fourth hour). $n=10$ paws in the $\alpha$ CaMKII group; $n=6$ paws in the vehicle group.

uation, a signature feature of the primed state (Reichling and Levine, 2009).

Prolongation of $\mathrm{PGE}_{2}$ hyperalgesia in rats primed by activation of $\alpha \mathrm{CaMKII}$ is prevented by inhibiting PKC $\varepsilon$ and local protein translation

A key feature of hyperalgesic priming is that the prolonged $\mathrm{PGE}_{2}$ hyperalgesia in the primed nociceptor is PKC $\varepsilon$ dependent (Aley et al., 2000; Parada et al., 2003a; Reichling and Levine, 2009). To confirm that this is also true for the neuroplastic change induced 


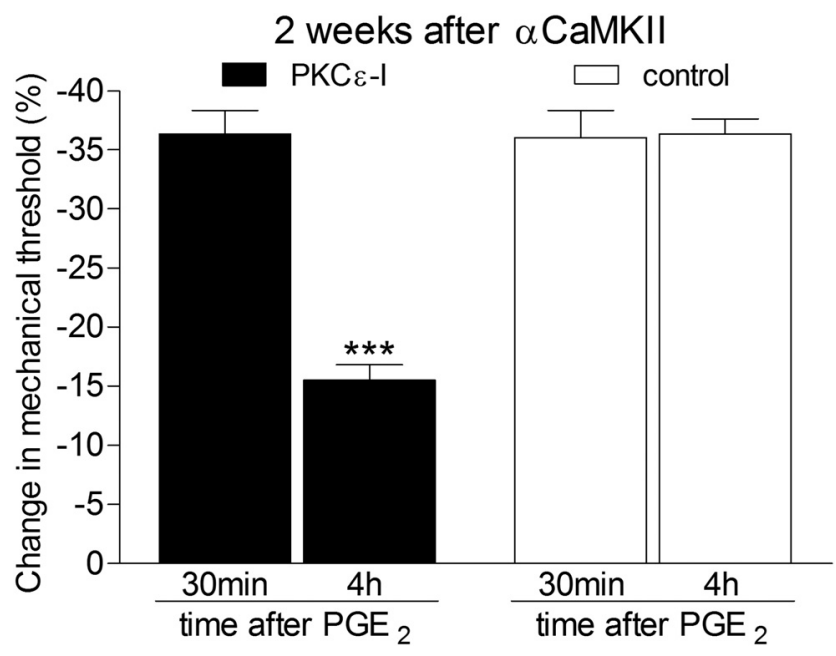

Figure 3. Prolongation of $\mathrm{PGE}_{2}$-induced mechanical hyperalgesia in $\alpha$ CaMKII primed rats is PKC $\varepsilon$ dependent. Activated $\alpha$ CaMKII $(25 \mathrm{ng})$ was injected intradermally in the rat hindpaw. Two weeks later, when the mechanical thresholds had returned to baseline (paired Student's $t$ test showed no difference in the mechanical thresholds between both groups; $t_{(10)}=1.340$, $p=0.2099$; data not shown), the PKC $\varepsilon$-specific translocation inhibitor peptide $\operatorname{PKC} \varepsilon V_{1-2}$ (PKC $\varepsilon-1,1 \mu \mathrm{g}$, filled bars), or its vehicle (control, open bars), was administered in the same site. Five minutes later, $\mathrm{PGE}_{2}(100 \mathrm{ng})$ was injected, and the mechanical nociceptive thresholds were evaluated $30 \mathrm{~min}$ and $4 \mathrm{~h}$ later. Significant attenuation of the prolonged $\mathrm{PGE}_{2}$-induced hyperalgesia, measured at $4 \mathrm{~h}$, was observed in the paws treated with PKC $\varepsilon-\mathrm{I}\left({ }^{* * *} p<0.001\right)$, when compared with the vehicle-treated group, without affecting hyperalgesia at the $30 \mathrm{~min}$ time point (two-way repeated-measures ANOVA followed by Bonferroni's post hoc test; $F_{(1,10)}=$ $27.36, p=0.0004$, both groups compared at $30 \mathrm{~min}$ ). $n=6$ paws per group.

by injection of activated $\alpha$ CaMKII, we administered the PKC $\varepsilon$ inhibitor (PKC $\varepsilon$-I), 5 min before $\mathrm{PGE}_{2}$, in rats previously treated (2 weeks before) with activated $\alpha$ CaMKII. As with priming induced by carrageenan, tumor necrosis factor $\alpha$ (TNF $\alpha$ ), or interleukin 6 (IL-6), $\mathrm{PGE}_{2}$-induced hyperalgesia in rats previously treated with activated $\alpha$ CaMKII was also attenuated by the PKC $\varepsilon$ inhibitor ( $p<0.001$; Fig. 3$)$. Thus, prior treatment with active $\alpha$ CaMKII produces a neuroplastic change in the nociceptor such that subsequent injection of $\mathrm{PGE}_{2}$ into its peripheral receptive field induces mechanical hyperalgesia, with the following two signature features of classic hyperalgesic priming: (1) marked prolongation of $\mathrm{PGE}_{2}$-induced hyperalgesia and (2) PKC $\varepsilon$ dependence of the prolongation of $\mathrm{PGE}_{2}$-induced hyperalgesia (Aley et al., 2000; Parada et al., 2003a; Reichling and Levine, 2009).

We have also previously shown that hyperalgesic priming induced by activation of PKC $\varepsilon$ is dependent on protein translation in the peripheral terminal of the nociceptor (Ferrari et al., 2013b). Thus, to further confirm that the neuroplastic change induced by injection of activated $\alpha$ CaMKII is hyperalgesic priming, we injected the protein translation inhibitors cordycepin $(1 \mu \mathrm{g}$; Fig. $4 A$ ) or rapamycin $(1 \mu \mathrm{g}$; Fig. $4 B)$, or their respective vehicles, intradermally at the site of nociceptive testing on the dorsum of the hindpaw previously injected with activated $\alpha$ CaMKII. Thirty minutes later, $\mathrm{PGE}_{2}$ was injected at the site of nociceptive testing. We found that both protein translation inhibitors, but not their vehicle, injected before $\mathrm{PGE}_{2}$ inhibited the ability of $\mathrm{PGE}_{2}$ to induce prolonged hyperalgesia induced by the previous injection of activated $\alpha$ CaMKII $(p<0.0001$ when the cordycepin and rapamycin groups were compared with their vehicles; Fig. 4, $A$ and $B$, respectively).
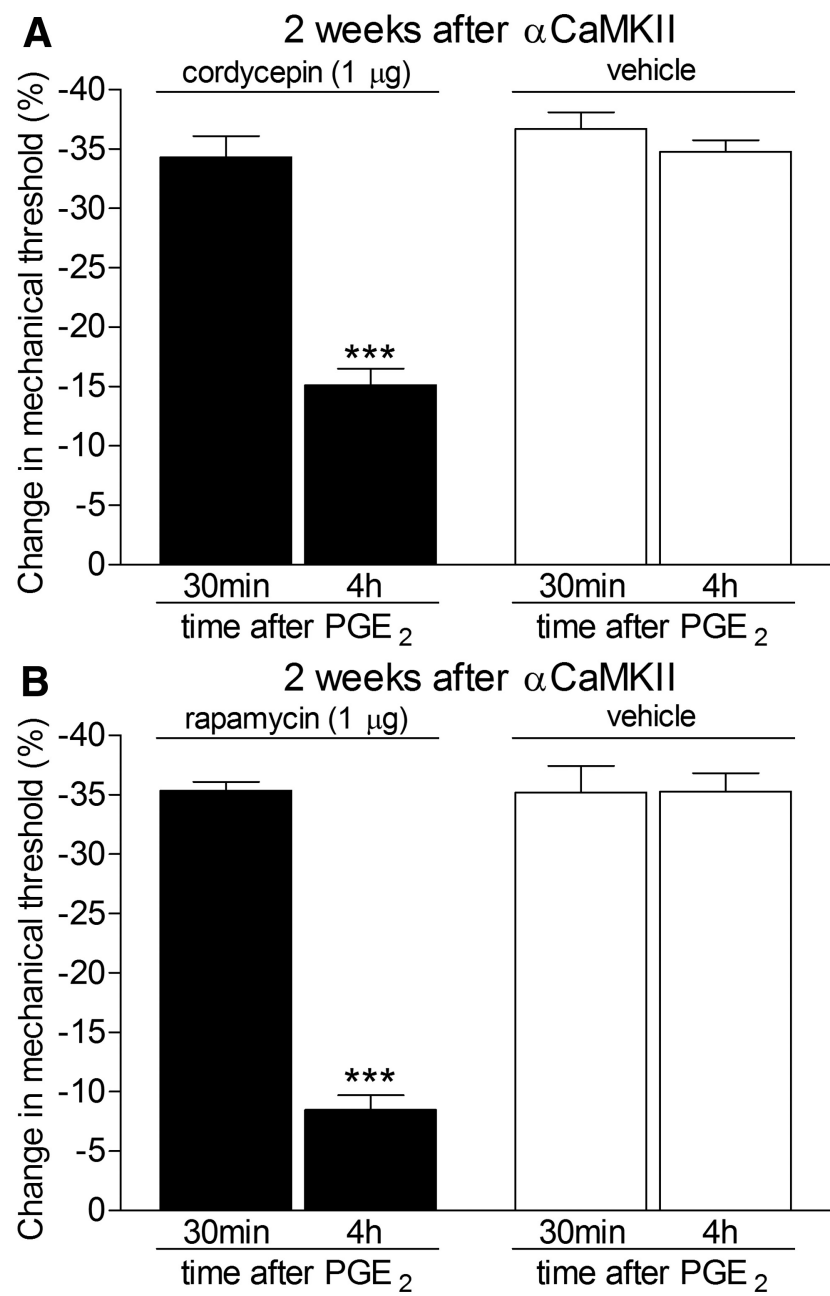

Figure 4. Prolongation of $\mathrm{PGE}_{2}$-induced mechanical hyperalgesia in $\alpha$ CaMKII primed rats is dependent on local protein translation. Activated $\alpha$ CaMKII ( $25 \mathrm{ng}$ ) was injected intradermally on the dorsum of the hindpaw of different groups of rats. Mechanical nociceptive threshold evaluation showed significant hyperalgesia $30 \mathrm{~min}$ and $4 \mathrm{~h}$ after injection and mechanical thresholds similar to baseline values on the day of the test with $\mathrm{PGE}_{2}$ ( 2 weeks after $\alpha$ CaMKII injection; data not shown). $\boldsymbol{A}, \boldsymbol{B}$, Injection of $\mathrm{PGE}_{2}(100 \mathrm{ng})$ at the same site as $\alpha$ CaMKII was preceded (30 min before) by injection of cordycepin $(\boldsymbol{A}, 1 \mu \mathrm{g}$, filled bars) or rapamycin $(\boldsymbol{B}, 1 \mu \mathrm{g}$, filled bars). Control groups received vehicle in the $\mathrm{PGE}_{2}$ injection site (open bars). Repeatedmeasures ANOVA followed by Bonferroni's post hoc test showed significant hyperalgesia, evaluated $30 \mathrm{~min}$ and $4 \mathrm{~h}$ after injection in the groups treated with vehicle; however, in the groups treated with cordycepin or rapamycin, the magnitude of the $\mathrm{PGE}_{2}$-induced hyperalgesia was significantly decreased at the fourth hour $\left(\boldsymbol{A}, F_{(1,10)}=44.42\right.$, ${ }^{* * *} p<0.0001 ; \boldsymbol{B}, F_{(1,10)}=$ $73,25,{ }^{* * *} p<0.0001$; when the protein translation inhibitor groups are compared with the vehicle groups), indicating an effect of protein translation inhibitors on the prolongation of the $\mathrm{PGE}_{2}$-induced hyperalgesia in paws primed with activated $\alpha$ CaMKII. $n=6$ paws per group.

\section{Induction of priming by $\alpha \mathrm{CaMKII}$ is not PKC $\varepsilon$ dependent}

We next tested the hypothesis that $\alpha \mathrm{CaMKII}$ is downstream of PKC $\varepsilon$ in the induction of hyperalgesic priming, since it can be activated by CPEB (Wu et al., 1998; Huang et al., 2002), which is, in turn, activated by PKC $\varepsilon$ (Bogen et al., 2012). If $\alpha$ CaMKII is downstream of PKC $\varepsilon$ in the induction of priming, then pretreatment with ODN AS to mRNA for PKC $\varepsilon$ should not prevent the development of priming by activated $\alpha$ CaMKII, as it does for priming induced by activation of cell-surface receptors for TNF $\alpha$ and IL-6 (Parada et al., 2003b; Dina et al., 2008, 2011). We found that treating animals with ODN AS for PKC $\varepsilon$ in a protocol that prevented priming induced by TNF $\alpha$ and IL-6 (Parada et al., 2003b; Dina et al., 2008, 2011) did not prevent the development 

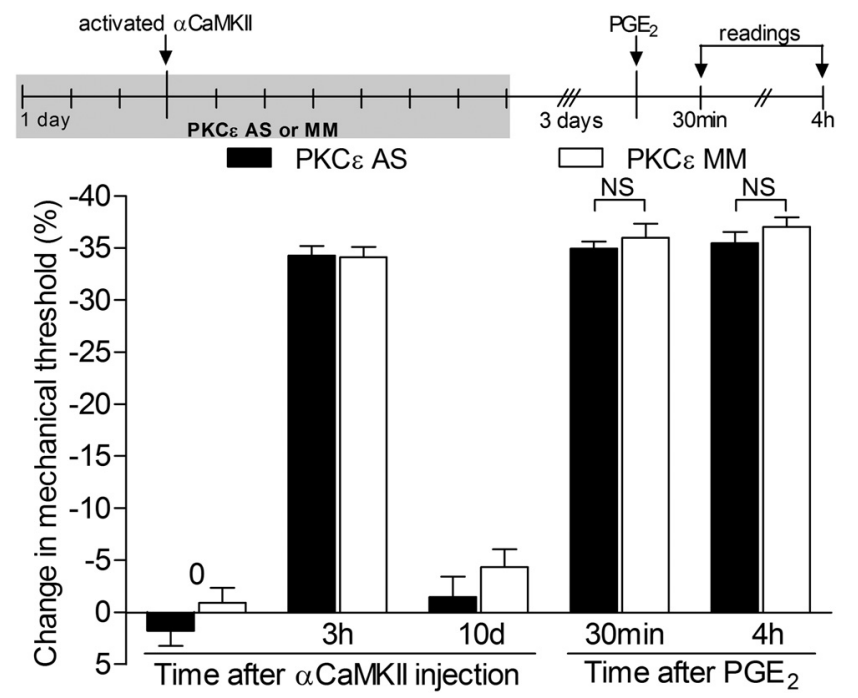

Figure 5. Induction of hyperalgesic priming by $\alpha$ CaMKII is not PKC $\varepsilon$ dependent. Rats were treated with ODN AS (filled bars) or MM (open bars) for PKC $\varepsilon$ mRNA for 10 consecutive days. Activated $\alpha$ CaMKII ( $25 \mathrm{ng}$ ) was injected on the dorsum of the hind paw on the third day of ODN AS or MM treatment. Three days after the last ODN treatment (on the 13th day), $\operatorname{PGE}_{2}(100 \mathrm{ng}$ ) was injected at the same site as activated $\alpha$ CaMKII (paired Student's $t$ test showed no significant difference between the mechanical thresholds in both groups before $\alpha$ CaMKII administration and immediately before $\mathrm{PGE}_{2}$ injection: $t_{(5)}=0.8660, p=0.4261$ for the AS group and $t_{(5)}=0.7559, p=0.4838$ for the MM group, respectively). Two-way repeated-measures ANOVA followed by Bonferroni's post hoc test showed that in both the AS and the MM groups the PGE $E_{2}$-induced mechanical hyperalgesia was still present at the fourth hour, indicating that PKC $\varepsilon$ is not necessary for the induction of priming by $\alpha$ CaMKII $\left(F_{(1,10)}=2.10 ; p=0.1784\right.$, when comparing both groups; NS). $n=6$ paws per group.

of priming induced by activated $\alpha$ CaMKII ( $p=0.1784$ when the ODN AS-treated group was compared with the ODN MMtreated group; Fig. 5).

\section{$\mathrm{PKC} \varepsilon$-induced hyperalgesic priming is dependent on activation of the RyR}

Since $\alpha$ CaMKII activation is calcium dependent (Hanson and Schulman, 1992; Pereda et al., 1998; Coultrap and Bayer, 2012) and in other forms of neuroplasticity this calcium is derived from activation of RyR (Cheng et al., 2010; Adasme et al., 2011; Stutzmann and Mattson, 2011), we determined whether blocking RyRs would prevent the induction of hyperalgesic priming by activation of PKCe. In this study, we found that pretreatment with the RyR inhibitor dantrolene prevented the development of priming by injection of the PKC $\varepsilon$ activator $\psi \varepsilon$ RACK $(p<0.001$; Fig. 6, gray bars). In addition, we also observed significant attenuation of $\psi \varepsilon$ RACK-induced priming by the pretreatment with a calcium chelator, TMB-8 ( $p<0.001$; Fig. 6 , filled bars), suggesting that calcium release by activation of the RyR plays a role in the induction of priming.

\section{Ryanodine produces priming}

$\alpha$ CaMKII is a calcium-dependent kinase (Hanson and Schulman, 1992; Pereda et al., 1998; Coultrap and Bayer, 2012) that has been shown to associate with the RyR (Shakiryanova et al., 2007, 2011; Wong et al., 2009), which can, when activated, induce localized high concentrations of calcium (Ehrlich et al., 1994; MacKrill, 1999, 2012). Thus, since activation of the RyR can also activate $\alpha$ CaMKII (Shakiryanova et al., 2007, 2011; Wong et al., 2009), we determined whether ryanodine, an RyR agonist (Meissner, 1986; Sattelle et al., 2008), could also induce priming. To determine whether activation of the RyR is sufficient to induce hyperalgesic

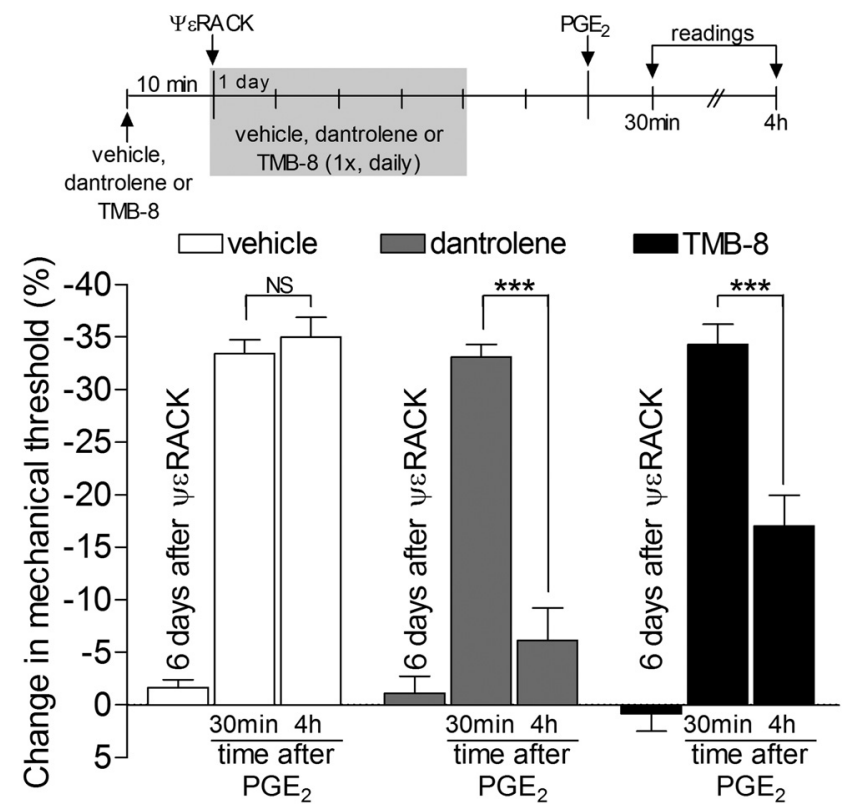

Figure 6. $P K C \varepsilon$-induced hyperalgesic priming is dependent on the RyR. Rats received intradermal injection of vehicle (white bars), dantrolene (1 $\mu \mathrm{g}$, gray bars), or TMB-8 (1 $\mu \mathrm{g}$, black bars) on the dorsum of the hindpaw. Ten minutes later, the PKC $\varepsilon$ activator $\psi \varepsilon$ RACK (1 $\mu \mathrm{g})$ was injected at the same site and the mechanical nociceptive thresholds were evaluated (data not shown). Daily injections of vehicle, dantrolene, or TMB-8 continued for $4 \mathrm{~d}$, until the mechanical thresholds had returned to baseline. Two days after the last injection ( $6 \mathrm{~d}$ after $\psi \varepsilon \mathrm{RACK}), \mathrm{PGE}_{2}$ (100 ng) was administered at the same site, and the mechanical thresholds were evaluated 30 min and $4 \mathrm{~h}$ later. Two-way repeated-measures ANOVA followed by Bonferroni's post hoc test showed significant mechanical hyperalgesia induced by $P G E_{2}$ in all groups $\left(F_{(2,30)}=24.01 ; p<\right.$ 0.0001 when compared with baseline mechanical thresholds). However, in the groups that received dantrolene or $T M B-8$, the $\mathrm{PGE}_{2}$-induced hyperalgesia was significantly attenuated at the $4 \mathrm{~h}$ time point $\left(^{* * *} p<0.001\right.$ for both groups when comparing 30 min and $4 \mathrm{~h}$ time points), in contrast with the vehicle-treated group (NS; $p>0.05$ ). $n=6$ paws per group.

priming, we injected ryanodine ( $1 \mu \mathrm{g}$ ) or its vehicle intradermally on the dorsum of the hindpaw. Ryanodine produced mechanical hyperalgesia, measured $30 \mathrm{~min}$ after its injection, which was no longer significant $7 \mathrm{~d}$ later (Fig. 7, filled bars). $\mathrm{PGE}_{2}$ (100 ng) was then injected at the site on the dorsum of the hindpaw where previously ryanodine or its vehicle had been injected. When $\mathrm{PGE}_{2}$ was injected in paws previously treated with ryanodine vehicle, it induced hyperalgesia that could be detected $30 \mathrm{~min}$ later but was back to baseline at $4 \mathrm{~h}$. In contrast, when injected in the paw previously treated with ryanodine, $\mathrm{PGE}_{2}$-induced hyperalgesia was still present $4 \mathrm{~h}$ later without attenuation, characteristic of the primed state $(p<0.001$, compared with the vehicle-treated group at the fourth hour; Fig. 7, filled bars). Therefore, to test the hypothesis that the ability of ryanodine to induce priming was mediated by its ability to induce an increase in calcium, we pretreated rats with the calcium buffer TMB-8 $(1 \mu \mathrm{g}) 5 \mathrm{~min}$ before injection of ryanodine. We found that prior injection of TMB-8 not only inhibited the hyperalgesic effect of ryanodine $(p<$ 0.001 ) but also prevented induction of priming, since the injection of $\mathrm{PGE}_{2}$ at the same site of ryanodine, 1 week later, did not produce prolonged hyperalgesia in the group treated with TMB- 8 , in contrast to the group treated with vehicle, in which the $\mathrm{PGE}_{2}$-induced hyperalgesia was still present at the fourth hour $(p<0.001$; Fig. 8).

\section{$\alpha \mathrm{CaMKII}$ is downstream of RyR in the induction of hyperalgesic priming}

To test whether the underlying mechanism of the priming produced by ryanodine is dependent on $\alpha$ CaMKII activation, rats 


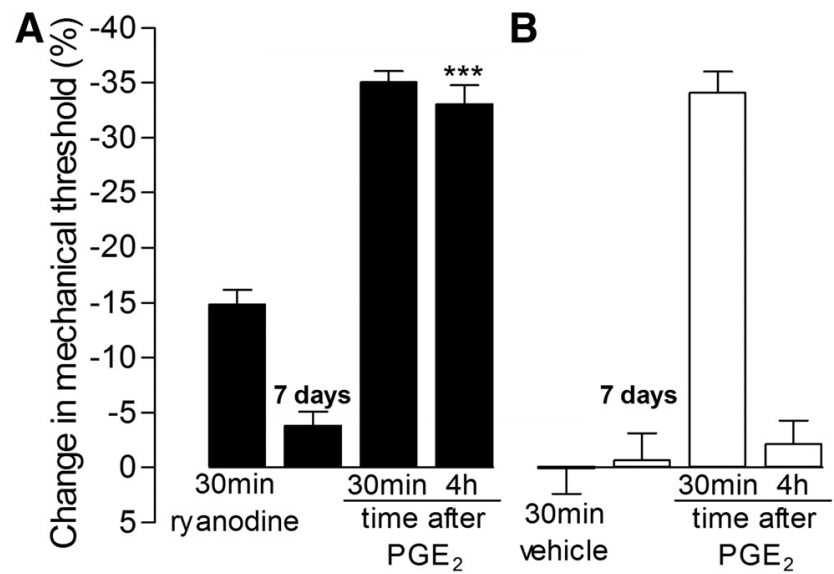

Figure 7. Ryanodine induces hyperalgesic priming. $\boldsymbol{A}, \boldsymbol{B}$, Rats received intradermal injection of ryanodine ( $\boldsymbol{A}, 1 \mu \mathrm{g}$, filled bars) or vehicle ( $\boldsymbol{B}$, open bars) on the dorsum of the hindpaw, and the mechanical nociceptive thresholds were evaluated 30 min later. Repeated-measures ANOVA showed significant mechanical hyperalgesia induced by ryanodine, but not by vehicle $\left(F_{(1,10)}=46.08 ; p<0.0001\right.$ when the ryanodine group is compared with the vehicle group). Testing for priming with intradermal injection of $\mathrm{PGE}_{2}$ $(100 \mathrm{ng})$ was performed $7 \mathrm{~d}$ later, when the mechanical nociceptive threshold had returned to pre-ryanodine baseline (paired Student's $t$ test showed no significant difference between the mechanical thresholds before and $7 \mathrm{~d}$ after ryanodine or vehicle administration; $t_{(5)}=0.1784, p=0.1048$ for the ryanodine group; $t_{(5)}=0.4385, p=0.6793$ for the vehicle group). Repeated-measures ANOVA followed by Bonferroni's post hoc test showed significant hyperalgesia induced by $\mathrm{PGE}_{2}$ injected at the same site as ryanodine or vehicle at $30 \mathrm{~min}$. And, in contrast to the vehicle group, in which the hyperalgesia was no longer present $4 \mathrm{~h}$ after $\mathrm{PGE}_{2}$ injection, in the paws that received ryanodine 1 week before, the $\mathrm{PGE}_{2}$-induced hyperalgesia was unattenuated $\left({ }^{* * *} p<0.001\right.$, when compared with the vehicle group). $n=6$ paws per group.
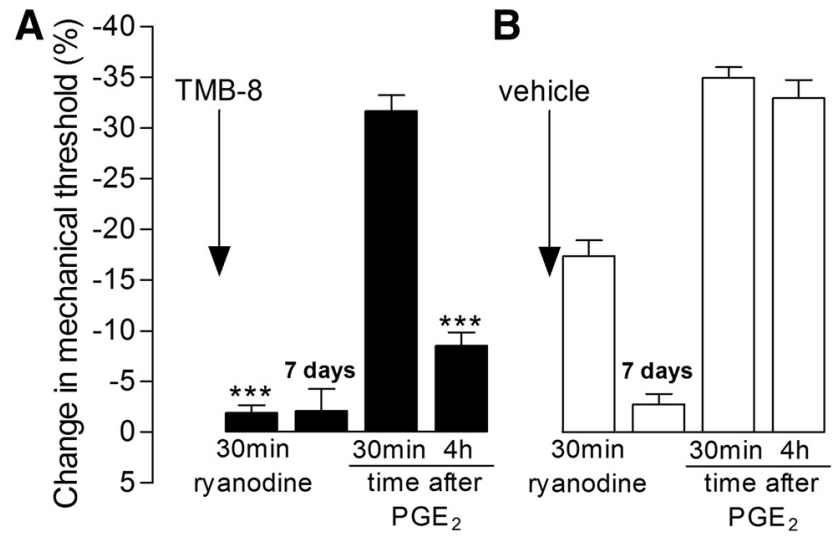

Figure 8. Ryanodine-induced priming is calcium dependent. $\boldsymbol{A}, \boldsymbol{B}$, Rats received intradermal injection of the calcium buffer TMB-8 ( $\boldsymbol{A}, 1 \mu \mathrm{g}$, filled bars) or its vehicle ( $\boldsymbol{B}$, open bars) on the dorsum of the hindpaw. Ten minutes later, ryanodine $(1 \mu \mathrm{g})$ was injected at the same site and the mechanical nociceptive thresholds were evaluated after $30 \mathrm{~min}$. Two-way repeatedmeasures ANOVA followed by Bonferroni's post hoc test showed significant mechanical hyperalgesia induced by ryanodine in the control group, as opposed to the group treated with TMB-8, in which the hyperalgesia was significantly attenuated $\left(F_{(1,20)}=15.67\right.$; ${ }^{* * *} p<0.001$ when both groups are compared $30 \mathrm{~min}$ after ryanodine injection). Seven days later, when the mechanical thresholds were back to baseline (paired Student's $t$ test showed no significant difference between the mechanical thresholds before and $7 \mathrm{~d}$ after ryanodine plus TMB-8 or ryanodine plus vehicle administration; $t_{(5)}=0.6547, p=0.5416$ and $t_{(5)}=0.7565, p=$ 0.3701 , respectively), testing for priming was performed by intradermal injection of $\mathrm{PGE}_{2}(100$ $\mathrm{ng}$ ) at the same site as ryanodine. Repeated-measures ANOVA followed by Bonferroni's post hoc test showed that the group treated with TMB-8, but not with vehicle, before ryanodine injection had a significant decrease in the $\mathrm{PGE}_{2}$-induced hyperalgesia at the fourth hour $\left(F_{(1,10)}=92.90\right.$; ${ }^{* * *} p<0.001$ when the TMB-8-treated group is compared with the vehicle-treated group at the fourth hour). $n=6$ paws per group.
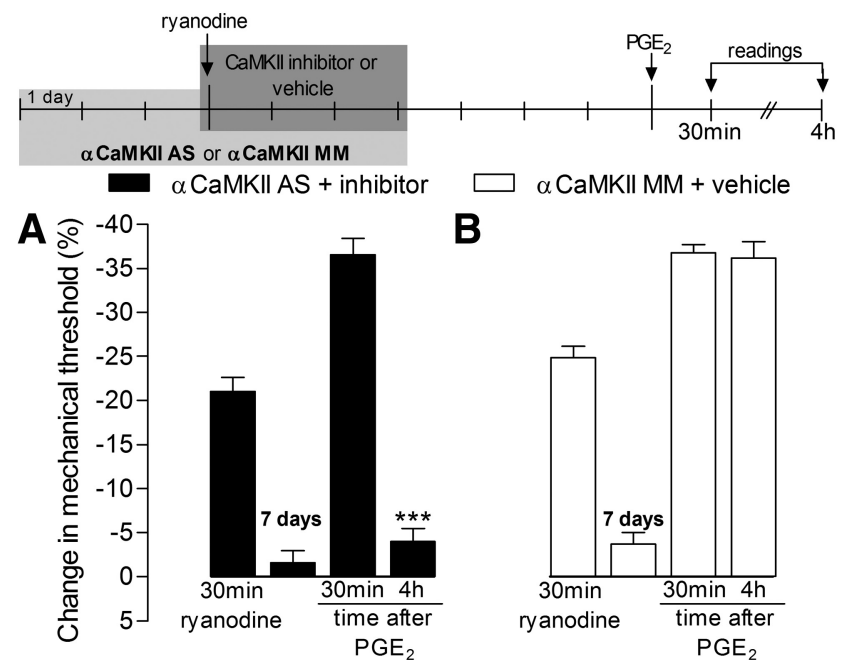

Figure 9. $\alpha$ CaMKII is downstream of the RyR in the induction of hyperalgesic priming. Rats were treated with ODN AS ( $\boldsymbol{A}$, filled bars) or MM ( $\boldsymbol{B}$, open bars) for $\alpha$ CaMKII for 6 consecutive days. On the third day of ODN AS or MM treatment, ryanodine $(1 \mu \mathrm{g})$ was coinjected with the CaMKII inhibitor CaM2INtide ( $\boldsymbol{A}, 1 \mu \mathrm{g}$, filled bars), or vehicle ( $\boldsymbol{B}$, open bars), on the dorsum of the hindpaws. Mechanical thresholds were evaluated 30 min later. Ryanodine induced mechanical hyperalgesia in both groups, without significant statistical difference between the groups (two-way repeated-measures ANOVA followed by Bonferroni's post hoc test; $F_{(1,20)}=2.04$; $p=0.1841$ ). The daily treatment with ODN AS plus CaMKII inhibitor or MM plus vehicle continued for 3 more days. PGE 2 (100 ng) was injected, $4 \mathrm{~d}$ after the ODN AS or MM treatment was discontinued, at the same site as the injection of ryanodine plus CaMKII inhibitor or vehicle. Repeated-measures ANOVA showed that the treatment with $\alpha$ CaMKII AS plus CaMKII inhibitor prevented the induction of priming by ryanodine, since the $\mathrm{PGE}_{2}$-induced hyperalgesia, although similar in both groups at the 30 min time point, was significantly attenuated in the AS plus inhibitor group but not on the MM plus vehicle group ( ${ }^{* * *} p<0.001$, when both groups are compared at the fourth hour). $n=6$ paws per group.

pretreated with ODN AS (filled bars) or MM (open bars) for $\alpha$ CaMKII for 3 consecutive days received coinjection of ryanodine $(1 \mu \mathrm{g})$ and the CaMKII inhibitor CaM2INtide ( $1 \mu \mathrm{g})$ (filled bars) or its vehicle (open bars) on the dorsum of the hindpaw (Fig. 9). The daily treatment with ODN AS or MM plus CaMKII inhibitor or vehicle continued for 3 more days, since it has been shown that priming takes $72 \mathrm{~h}$ to develop (Bogen et al., 2012). Four days after the ODN treatment was discontinued, $\mathrm{PGE}_{2}$ was injected at the same site as ryanodine, CaMKII inhibitor, or vehicle. We found that in the rats that had the activation of $\alpha$ CaMKII prevented by the treatment with ODN AS and the CaMKII inhibitor, but not in the group treated with $\mathrm{MM}$ and vehicle, the $\mathrm{PGE}_{2}$ induced hyperalgesia was significantly attenuated at the fourth hour, suggesting that the priming induced by ryanodine is dependent on $\alpha$ CaMKII activation $(p<0.001$; Fig. 9).

\section{Hyperalgesic priming in females}

In previous studies in which hyperalgesic priming was induced by agents that act at receptors on the nociceptor terminal (e.g., TNF $\alpha$ or IL-6; Aley et al., 2000; Parada et al., 2003b; Dina et al., 2008 , 2011) or by direct activation of $\mathrm{PKC} \varepsilon$, using the PKC $\varepsilon$ selective agonist $\psi \varepsilon$ RACK (Aley et al., 2000), while priming was induced in male rats, the same experimental protocol did not induce priming in female rats (Joseph et al., 2003). To determine whether the sexual dimorphism in induction of priming is caused by sex differences in male and female rats proximally in the intracellular pathway leading to the production of priming, activated $\alpha$ CaMKII (25 ng; Fig. 10A, gray bars) or ryanodine ( $1 \mu \mathrm{g}$; Fig. $10 B$, gray bars) was injected intradermally on the dorsum of the hindpaw of the female rat. At the same time after their injec- 
tion that induced priming in male rats, both activated $\alpha$ CaMKII and ryanodine induced prolonged $\mathrm{PGE}_{2}$ hyperalgesia in the female rat (Fig. 10, $A$ and $B$, respectively; $p<0.001$ in both cases compared with the control groups). Thus, activation of molecules downstream but not upstream of $\mathrm{PKC} \varepsilon$ produces hyperalgesic priming in the female as well as the male rat.

\section{Discussion}

Although chronic pain remains one of the most costly items in the health care budget of developed countries (de Girolamo, 1991; Langley et al., 2010; Langley, 2011; Anastassopoulos et al., 2012; Gaskin and Richard, 2012), progress toward its effective management, much less reversal of the responsible underlying neuroplastic changes in the pain pathway, has experienced limited improvement. To approach this problem, we have developed a model of the transition from acute to chronic pain in which, after recovery from an inflammatory insult that produces $\mathrm{PKC} \varepsilon$ dependent nociceptor sensitization, a subsequent exposure to an inflammatory mediator with a receptor on the primary afferent nociceptor produces enhanced, and markedly prolonged, PKC $\varepsilon$-dependent hyperalgesia. Hyperalgesic priming is mediated by changes in intracellular signaling pathways that underlie mechanical hyperalgesia induced by inflammatory mediators, such as $\mathrm{PGE}_{2}$ (Aley et al., 2000; Parada et al., 2005; Ferrari et al., 2013a). Since hyperalgesic priming is still present, unattenuated, for months after its induction (Aley et al., 2000; Parada et al., 2005), it is likely caused by a phenotypic switch in primary afferent nociceptors. However, given the continuous turnover of most cellular proteins, it is difficult to conceive that a simple switch in the coupling of a G-protein-coupled receptor to a different second-messenger signaling pathway (Parada et al., 2005; Khasar et al., 2008; Dina et al., 2009; Ferrari et al., 2013a) is sufficient to explain the endurance of the plasticity associated with hyperalgesic priming.

In a follow-up study of the mechanism of hyperalgesic priming, we have shown that downregulation of the level of expression of CPEB, an RNA-binding molecule that regulates the translation of otherwise dormant mRNAs (Richter, 2007; Villalba et al., 2011), that is almost exclusively expressed by IB4(+) nociceptors (the subset of nociceptors in which hyperalgesic priming occurs; Joseph and Levine, 2010), and that can be coimmunoprecipitated with $\mathrm{PKC} \varepsilon$, by the intrathecal administration of ODN
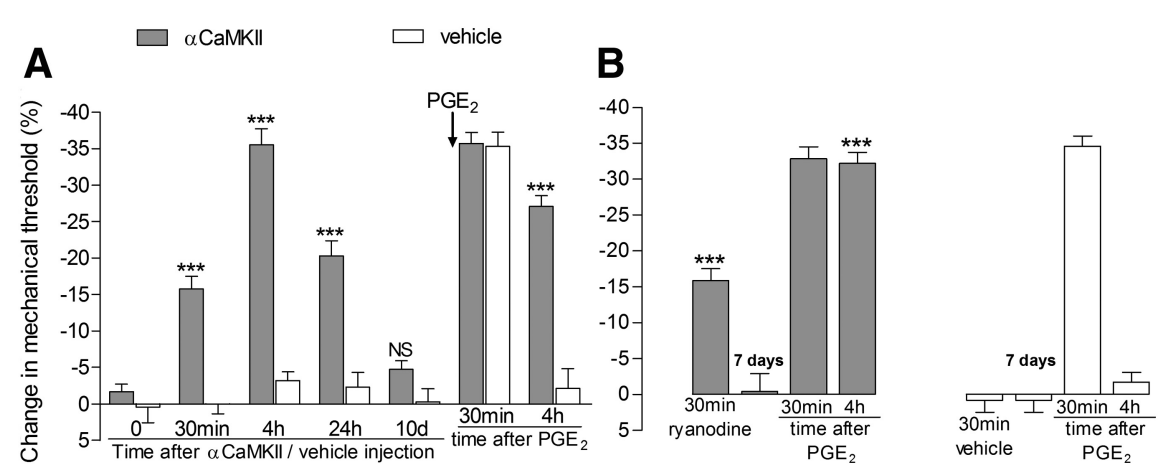

Figure 10. $\alpha$ CaMKII and ryanodine induce priming in female rats. $\boldsymbol{A}$, Female rats received intradermal injection of activated $\alpha$ CaMKII ( $25 \mathrm{ng}$, gray bars) or its vehicle (white bars). Mechanical nociceptive threshold was evaluated before and $30 \mathrm{~min}, 4 \mathrm{~h}, 24 \mathrm{~h}$, and $10 \mathrm{~d}$ after their injection. Two-way repeated-measures ANOVA followed by Bonferroni's post hoc test showed significant hyperalgesia in the $\alpha$ CaMKII-treated group but not in the vehicle-treated group $\left(F_{(1,40)}=162.26\right.$; $\left.{ }^{* * *} p<0.001\right)$, with no significant (NS) difference between both groups on the 10th day. Test for priming was then performed with intradermal injection of $\mathrm{PGE}_{2}(100 \mathrm{ng})$ on day 10 . Repeated-measures ANOVA showed that $\mathrm{PGE}_{2}$-induced hyperalgesia was still significant at the fourth hour in the $\alpha$ CaMKII-treated paws, whereas in the vehicle-treated group, the mechanical threshold had already returned to baseline values at that time point $\left(F_{(1,10)}=26.61 ;{ }^{* * *} p<0.001\right.$ when both groups are compared at the fourth hour). $n=6$ paws per group. $\boldsymbol{B}$, Ryanodine (1 $\mu \mathrm{g}$, gray bars) or vehicle (white bars) was injected intradermally on the dorsum of the hindpaw of female rats, and the mechanical thresholds were evaluated $30 \mathrm{~min}$ later. Significant hyperalgesia was observed in the ryanodinetreated group but not in the vehicle-treated paws 30 min after injection $\left({ }^{* * *} p<0.001\right.$, when ryanodine group is compared with the vehicle group). Seven days after ryanodine or vehicle injection, $\mathrm{PGE}_{2}(100 \mathrm{ng})$ was injected at the same site (paired Student's test showed no significant difference between the mechanical thresholds before and $7 \mathrm{~d}$ after ryanodine or vehicle administration: $t_{(5)}=1.225, p=0.2752$ and $t_{(5)}=1.035, p=0.3481$, respectively). Two-way repeated-measures ANOVA followed by Bonferroni's post hoc test showed that the $P \mathrm{PG}_{2}$-induced mechanical hyperalgesia was still present $4 \mathrm{~h}$ after injection in the rats that previously received ryanodine, whereas in the group that received vehicle, the nociceptive thresholds had returned to baseline at that time point $\left(F_{(1,10)}=55.24 ;{ }^{* * *} p<0.001\right) . n=6$ paws per group.

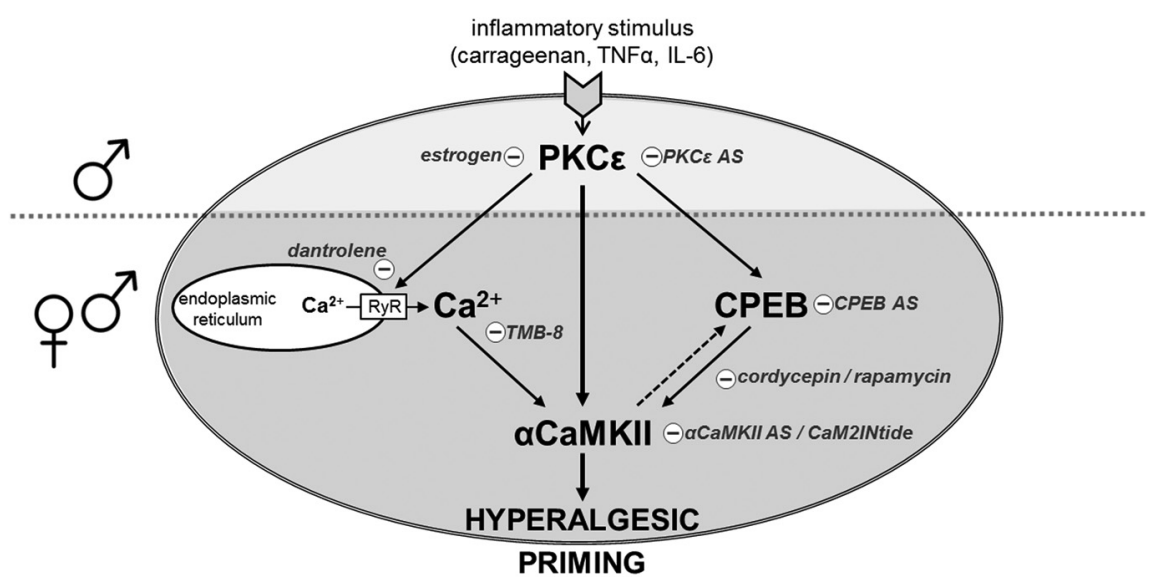

Figure 11. Schematic diagram of the proposed mechanisms underlying the induction of hyperalgesic priming in male and female rats. In male but not female rats, activation of TNF $\alpha$ and IL-6 receptors or direct activation of PKC $\varepsilon$ in the peripheral terminal of the primary afferent nociceptor triggers a cascade of events that culminate in hyperalgesic priming. CPEB, a downstream target of $\mathrm{PKC} \varepsilon$, activates $\alpha$ CaMKIl in the induction of priming. In the PKC $\varepsilon$-induced priming, $\alpha$ CaMKIl is downstream of CPEB. However, since $\alpha$ CaMKIl is also able to affect CPEB activity (dashed arrow) (Atkins et al., 2004), the maintenance of the primed state is hypothesized to be a loop in which $\alpha$ CaMKII is both upstream and downstream of CPEB. Importantly, activation of $\alpha$ CaMKII induces priming in male and female rats (events below the dotted line are involved in priming in both sexes). Direct activation of RyR also produces priming in male and female rats by releasing calcium (Ehrlich et al., 1994; MacKrill, 1999, 2012) and activating $\alpha$ CaMKII (Shakiryanova etal., 2007, 2011; Wong etal., 2009). In italics are shown the inhibitors of the mediators involved in the induction of priming, with the respective steps on the pathway where they act: PKC $\varepsilon$ AS, CPEB AS, $\alpha$ CaMKII AS and the CaMKII inhibitor CaMINtide; the RyR inhibitor dantrolene; the calcium chelator TMB-8; and the protein translation inhibitors cordycepin and rapamycin. In addition, estrogen is the critical mediator that prevents the development of hyperalgesic priming in female rats, acting at the level of PKC $\varepsilon$ (Joseph et al., 2003).

AS targeting its mRNA, can prevent (Bogen et al., 2012), but not reverse (our unpublished observations), the neuroplastic change in the primary afferent nociceptor that underlies hyperalgesic priming. Because our ODN AS to CPEB mRNA only decreased CPEB by $28 \%$ in peripheral nerves, we considered that we might 
not be inhibiting peripheral translation to a degree required to produce permanent reversal of priming, which may need to be far more complete than that needed to prevent the development of priming. Importantly in this regard, we have recently shown that local injection of protein translation inhibitors (i.e., rapamycin and cordycepin) reversed as well as prevented the induction of priming (Ferrari et al., 2013b), suggesting a role of local protein synthesis in maintaining the neuroplastic change in the nociceptor in our model of the transition from acute to chronic pain. To begin to explore the nature of the dormant mRNA species in the peripheral axon of the primary afferent nociceptor, whose protein product mediates the contribution of CPEB to hyperalgesic priming, we evaluated the possible role of $\alpha$ CaMKII. The translation of $\alpha \mathrm{CaMKII}$ is regulated by CPEB (Wu et al., 1998). Moreover, it has been reported to be in the axons of sensory neurons (VanBerkum and Goodman, 1995; Hiruma et al., 1999; Geddis and Rehder, 2003; Gleason et al., 2003) and has been implicated in neuroplasticity in neurons in the CNS involved in learning and memory (Cammarota et al., 2002; Gleason et al., 2003; Yamauchi, 2005; Buard et al., 2010; Coultrap et al., 2010; Jama et al., 2011), making it a candidate for one of the dormant mRNA species contributing to the neuroplastic changes associated with hyperalgesic priming. In this study, we found that inhibition of $\alpha$ CaMKII was able to prevent the induction of priming by $\psi \varepsilon$ RACK (Fig. 1) and that the direct activation of $\alpha$ CaMKII induced priming independent of PKC $\varepsilon$ (Fig. 5). These results suggest $\alpha \mathrm{CaMKII}$ as a downstream target of PKC $\varepsilon$ in the events responsible for the induction of hyperalgesic priming. Moreover, similar to PKC $\varepsilon$-induced priming (Bogen et al., 2012), $\alpha$ CaMKII-induced priming was also dependent on protein translation (Fig. 4), suggesting an interaction of $\alpha$ CaMKII and CPEB in our model of transition from acute to chronic pain.

An important unanswered question is how activation of $\alpha \mathrm{CaMKII}$, which is known to be downstream of CPEB (Wu et al., 1998; Huang et al., 2002), induces translation-dependent priming in nociceptors. Of note in this regard, $\alpha$ CaMKII has been reported not only to be downstream of CPEB (Wu et al., 1998; Huang et al., 2002) but also to function upstream, regulating the function of CPEB by phosphorylation at the regulatory site threonine 171 (Atkins et al., 2004). Such positive feedback, in which peripheral protein translation is able to signal to dormant $\alpha$ CaMKII mRNA in sensory neurons axons and to enhance CPEB signaling by $\alpha$ CaMKII activity, could help explain why it is so difficult to reverse hyperalgesic priming and supports the suggestion that prevention may be a more tractable therapeutic option than reversal of chronic pain.

Given that $\alpha$ CaMKII is activated by calcium and that activation of the RyR, found on mitochondria (Beutner et al., 2001; Ryu et al., 2011; Yi et al., 2012) and the endoplasmic reticulum (Hasselbach and Migala, 1988; Witcher et al., 1991; Zalk et al., 2007; Currie, 2009; Kho et al., 2012; Van Petegem, 2012), the former which has been shown to be in high concentration of peripheral terminals of nociceptors (Morris and Hollenbeck, 1995; Chada and Hollenbeck, 2003, 2004; Ramírez and Couve, 2011), is capable of activating $\alpha$ CaMKII (Wong et al., 2009; Shakiryanova et al., 2011), we tested the hypothesis that activation of the RyR can also induce hyperalgesic priming. We found that ryanodine, the classic agonist at the RyR, does induce hyperalgesic priming (Fig. 7). To confirm that the effect of ryanodine was, in fact, attributable to an associated increase in calcium, we used the calcium chelator
TMB- 8 to buffer the increase in calcium induced by activation of the RyR. We found that administration of TMB-8, before ryanodine, prevented induction of hyperalgesic priming by ryanodine (Fig. 8) but not that induced by activated $\alpha$ CaMKII (data not shown). The most parsimonious explanation for these findings is that increases in calcium by activation of the RyR, which is capable of producing a focal high concentration of calcium and which is found in close proximity to $\alpha$ CaMKII, activates $\alpha$ CaMKII to produce hyperalgesic priming. And the fact that $\alpha$ CaMKII can be both upstream and downstream of CPEB could provide a form of positive feedback that might underlie the long-term perseverance of hyperalgesic priming, which can only be permanently reversed by inhibition of protein translation in the peripheral terminal of the nociceptor (Ferrari et al., 2013b).

An important, shortcoming of our model has been its failure to explain the transition from acute to chronic pain in females (Joseph et al., 2003). With access to mechanisms involved in hyperalgesic priming downstream of $\mathrm{PKC} \varepsilon$, we evaluated whether their direct activation can induce priming in the female rat as it does in the male. In contrast to the failure of activation of proximal mechanisms to induce hyperalgesic priming, such as TNF $\alpha$, IL-6, and inflammatory mediators induced by carrageenan, acting at cell-surface receptors, or by the PKC $\varepsilon$ activator $\psi \varepsilon$ RACK (Aley et al., 2000; Parada et al., 2003b; Dina et al., 2008, 2011), direct activation of distal mechanisms (i.e., $\alpha$ CaMKII or RyR) did induce priming in female rats. Confirmation of similarities in the mechanism for hyperalgesic priming in the female and male rat comes from our finding that $\mathrm{PGE}_{2}$-induced prolonged hyperalgesia is mediated by $\mathrm{PKC} \varepsilon$ and that translation inhibitors reverse hyperalgesic priming in the female rat (data not shown) as it does in the male (Ferrari et al., 2013b). What remains to be elucidated here are signaling pathways upstream of $\alpha$ CaMKII that can produce hyperalgesic priming in the female.

In conclusion, in this study we have further pursued the downstream mechanism mediating hyperalgesic priming, a model of the transition from acute to chronic pain that can be induced by inflammatory mediators such as TNF $\alpha$ and IL- 6 or by activation of $\mathrm{PKC} \varepsilon$ in the peripheral terminal of the nociceptor and involves protein translation of dormant mRNA in the nociceptor. We now provide evidence that $\alpha$ CaMKII, whose mRNA species is a downstream target of CPEB, plays a key role in the induction of hyperalgesic priming. That peripheral administration of translation inhibitors permanently reverses hyperalgesic priming induced by activation of $\alpha$ CaMKII suggested that $\alpha$ CaMKII could function upstream of CPEB. Based on these findings, we suggest the existence of a self-propagating positive feedback loop between $\alpha$ CaMKII and CPEB that is responsible for the neuroplastic changes in the nociceptor under primed conditions that could contribute to chronic pain (Fig. 11).

\section{References}

Adasme T, Haeger P, Paula-Lima AC, Espinoza I, Casas-Alarcon MM, Carrasco MA, Hidalgo C (2011) Involvement of ryanodine receptors in neurotrophin-induced hippocampal synaptic plasticity and spatial memory formation. Proc Natl Acad Sci US A 108:3029-3034. CrossRef Medline

Aley KO, Messing RO, Mochly-Rosen D, Levine JD (2000) Chronic hypersensitivity for inflammatory nociceptor sensitization mediated by the epsilon isozyme of protein kinase C. J Neurosci 20:4680-4685. Medline

Anastassopoulos KP, Chow W, Tapia CI, Baik R, Ackerman SJ, Biondi D, Kim MS (2012) Economic study on the impact of side effects in patients taking oxycodone controlled-release for noncancer pain. J Manag Care Pharm 18:615-626. Medline

Atkins CM, Nozaki N, Shigeri Y, Soderling TR (2004) Cytoplasmic polyadenylation element binding protein-dependent protein synthesis is regu- 
lated by calcium/calmodulin-dependent protein kinase II. J Neurosci 24: 5193-5201. CrossRef Medline

Beutner G, Sharma VK, Giovannucci DR, Yule DI, Sheu SS (2001) Identification of a ryanodine receptor in rat heart mitochondria. J Biol Chem 276:21482-21488. CrossRef Medline

Bilsky EJ, Wang T, Lai J, Porreca F (1996) Selective blockade of peripheral delta opioid agonist induced antinociception by intrathecal administration of delta receptor antisense oligodeoxynucleotide. Neurosci Lett 220: 155-158. CrossRef Medline

Bogen O, Alessandri-Haber N, Chu C, Gear RW, Levine JD (2012) Generation of a pain memory in the primary afferent nociceptor triggered by PKCepsilon activation of CPEB. J Neurosci 32:2018-2026. CrossRef Medline

Borle AB, Snowdowne KW (1982) Measurement of intracellular free calcium in monkey kidney cells with aequorin. Science 217:252-254. CrossRef Medline

Buard I, Coultrap SJ, Freund RK, Lee YS, Dell'Acqua ML, Silva AJ, Bayer KU (2010) CaMKII "autonomy" is required for initiating but not for maintaining neuronal long-term information storage. J Neurosci 30:82148220. CrossRef Medline

Burch RM, Axelrod J (1987) Dissociation of bradykinin-induced prostaglandin formation from phosphatidylinositol turnover in Swiss 3T3 fibroblasts: evidence for $\mathrm{G}$ protein regulation of phospholipase A2. Proc Natl Acad Sci U S A 84:6374-6378. CrossRef Medline

Cammarota M, Bevilaqua LR, Viola H, Kerr DS, Reichmann B, Teixeira V, Bulla M, Izquierdo I, Medina JH (2002) Participation of CaMKII in neuronal plasticity and memory formation. Cell Mol Neurobiol 22:259267. CrossRef Medline

Chada SR, Hollenbeck PJ (2003) Mitochondrial movement and positioning in axons: the role of growth factor signaling. J Exp Biol 206:1985-1992. CrossRef Medline

Chada SR, Hollenbeck PJ (2004) Nerve growth factor signaling regulates motility and docking of axonal mitochondria. Curr Biol 14:1272-1276. CrossRef Medline

Cheng LZ, Lü N, Zhang YQ, Zhao ZQ (2010) Ryanodine receptors contribute to the induction of nociceptive input-evoked long-term potentiation in the rat spinal cord slice. Mol Pain 6:1-11. Medline

Churn SB, Sombati S, Jakoi ER, Severt L, DeLorenzo RJ (2000) Inhibition of calcium/calmodulin kinase II alpha subunit expression results in epileptiform activity in cultured hippocampal neurons. Proc Natl Acad Sci U S A 97:5604-5609. CrossRef Medline

Coultrap SJ, Bayer KU (2012) CaMKII regulation in information processing and storage. Trends Neurosci 35:607-618. CrossRef Medline

Coultrap SJ, Buard I, Kulbe JR, Dell'Acqua ML, Bayer KU (2010) CaMKII autonomy is substrate-dependent and further stimulated by $\mathrm{Ca} 2+/ \mathrm{cal}-$ modulin. J Biol Chem 285:17930-17937. CrossRef Medline

Currie S (2009) Cardiac ryanodine receptor phosphorylation by CaM kinase II: keeping the balance right. Front Biosci 14:5134-5156. CrossRef Medline

de Girolamo G (1991) Epidemiology and social costs of low back pain and fibromyalgia. Clin J Pain 7 [Suppl 1]:S1-S7. Medline

Dina OA, Green PG, Levine JD (2008) Role of interleukin-6 in chronic muscle hyperalgesic priming. Neuroscience 152:521-525. CrossRef Medline

Dina OA, Khasar SG, Gear RW, Levine JD (2009) Activation of Gi induces mechanical hyperalgesia poststress or inflammation. Neuroscience 160: 501-507. CrossRef Medline

Dina OA, Levine JD, Green PG (2011) Enhanced cytokine-induced mechanical hyperalgesia in skeletal muscle produced by a novel mechanism in rats exposed to unpredictable sound stress. Eur J Pain 15:796-800. CrossRef Medline

Ehrlich BE, Kaftan E, Bezprozvannaya S, Bezprozvanny I (1994) The pharmacology of intracellular $\mathrm{Ca}(2+)$-release channels. Trends Pharmacol Sci 15:145-149. CrossRef Medline

Ferrari LF, Bogen O, Levine JD (2010) Nociceptor subpopulations involved in hyperalgesic priming. Neuroscience 165:896-901. CrossRef Medline

Ferrari LF, Bogen O, Alessandri-Haber N, Levine E, Gear RW, Levine JD (2012) Transient decrease in nociceptor GRK2 expression produces long-term enhancement in inflammatory pain. Neuroscience 222: 392-403. CrossRef Medline

Ferrari LF, Levine E, Levine JD (2013a) Role of a novel nociceptor autocrine mechanism in chronic pain. Eur J Neurosci 37:1705-1713. CrossRef Medline
Ferrari LF, Bogen O, Chu C, Levine JD (2013b) Peripheral administration of translation inhibitors reverses increased hyperalgesia in a model of chronic pain in the rat. J Pain. Advance online publication. Retrieved May 7, 2013. doi:10.1016/j.jpain.2013.01.779. CrossRef Medline

Gaskin DJ, Richard P (2012) The economic costs of pain in the United States. J Pain 13:715-724. CrossRef Medline

Geddis MS, Rehder V (2003) The phosphorylation state of neuronal processes determines growth cone formation after neuronal injury. J Neurosci Res 74:210-220. CrossRef Medline

Gleason MR, Higashijima S, Dallman J, Liu K, Mandel G, Fetcho JR (2003) Translocation of CaM kinase II to synaptic sites in vivo. Nat Neurosci 6:217-218. CrossRef Medline

Hanson PI, Schulman H (1992) Neuronal Ca2+/calmodulin-dependent protein kinases. Annu Rev Biochem 61:559-601. CrossRef Medline

Hasselbach W, Migala A (1988) Interaction of ryanodine with the calcium releasing system of sarcoplasmic reticulum vesicles. Z Naturforsch C 43 : $140-148$. Medline

Hiruma H, Maruyama H, Katakura T, Simada ZB, Nishida S, Hoka S, Takenaka T, Kawakami T (1999) Axonal transport is inhibited by a protein kinase $\mathrm{C}$ inhibitor in cultured isolated mouse dorsal root ganglion cells. Brain Res 826:135-138. CrossRef Medline

Huang YS, Jung MY, Sarkissian M, Richter JD (2002) N-methyl-Daspartate receptor signaling results in Aurora kinase-catalyzed CPEB phosphorylation and alpha CaMKII mRNA polyadenylation at synapses. EMBO J 21:2139-2148. CrossRef Medline

Jama AM, Gabriel J, Al-Nagar AJ, Martin S, Baig SZ, Soleymani H, Chowdhury Z, Beesley P, Török K (2011) Lobe-specific functions of $\mathrm{Ca} 2+$.calmodulin in alphaCa2+.calmodulin-dependent protein kinase II activation. J Biol Chem 286:12308-12316. CrossRef Medline

Johnson JA, Gray MO, Chen CH, Mochly-Rosen D (1996) A protein kinase C translocation inhibitor as an isozyme-selective antagonist of cardiac function. J Biol Chem 271:24962-24966. CrossRef Medline

Joseph EK, Levine JD (2010) Hyperalgesic priming is restricted to isolectin B4-positive nociceptors. Neuroscience 169:431-435. CrossRef Medline

Joseph EK, Parada CA, Levine JD (2003) Hyperalgesic priming in the rat demonstrates marked sexual dimorphism. Pain 105:143-150. CrossRef Medline

Khasar SG, Lin YH, Martin A, Dadgar J, McMahon T, Wang D, Hundle B, Aley KO, Isenberg W, McCarter G, Green PG, Hodge CW, Levine JD, Messing RO (1999) A novel nociceptor signaling pathway revealed in protein kinase C epsilon mutant mice. Neuron 24:253-260. CrossRef Medline

Khasar SG, Burkham J, Dina OA, Brown AS, Bogen O, Alessandri-Haber N, Green PG, Reichling DB, Levine JD (2008) Stress induces a switch of intracellular signaling in sensory neurons in a model of generalized pain. J Neurosci 28:5721-5730. CrossRef Medline

Kho C, Lee A, Hajjar RJ (2012) Altered sarcoplasmic reticulum calcium cycling-targets for heart failure therapy. Nat Rev Cardiol 9:717-733. CrossRef Medline

Langley P, Müller-Schwefe G, Nicolaou A, Liedgens H, Pergolizzi J, Varrassi G (2010) The societal impact of pain in the European Union: health-related quality of life and healthcare resource utilization. J Med Econ 13:571-581. CrossRef Medline

Langley PC (2011) The prevalence, correlates and treatment of pain in the European Union. Curr Med Res Opin 27:463-480. CrossRef Medline

MacKrill JJ (1999) Protein-protein interactions in intracellular Ca2+release channel function. Biochem J 337:345-361. CrossRef Medline

MacKrill JJ (2012) Ryanodine receptor calcium release channels: an evolutionary perspective. Adv Exp Med Biol 740:159-182. CrossRef Medline

Meissner G (1986) Ryanodine activation and inhibition of the Ca2 + release channel of sarcoplasmic reticulum. J Biol Chem 261:6300-6306. Medline

Mestre C, PélissierT, Fialip J, Wilcox G, Eschalier A (1994) A method to perform direct transcutaneous intrathecal injection in rats. J Pharmacol Toxicol Methods 32:197-200. CrossRef Medline

Morris RL, Hollenbeck PJ (1995) Axonal transport of mitochondria along microtubules and F-actin in living vertebrate neurons. J Cell Biol 131: 1315-1326. CrossRef Medline

Ouseph AK, Khasar SG, Levine JD (1995) Multiple second messenger systems act sequentially to mediate rolipram-induced prolongation of prostaglandin E2-induced mechanical hyperalgesia in the rat. Neuroscience 64:769-776. CrossRef Medline

Parada CA, Yeh JJ, Reichling DB, Levine JD (2003a) Transient attenuation 
of protein kinase Cepsilon can terminate a chronic hyperalgesic state in the rat. Neuroscience 120:219-226. CrossRef Medline

Parada CA, Yeh JJ, Joseph EK, Levine JD (2003b) Tumor necrosis factor receptor type-1 in sensory neurons contributes to induction of chronic enhancement of inflammatory hyperalgesia in rat. Eur J Neurosci 17: 1847-1852. CrossRef Medline

Parada CA, Reichling DB, Levine JD (2005) Chronic hyperalgesic priming in the rat involves a novel interaction between cAMP and PKCepsilon second messenger pathways. Pain 113:185-190. CrossRef Medline

Pereda AE, Bell TD, Chang BH, Czernik AJ, Nairn AC, Soderling TR, Faber DS (1998) Ca2+/calmodulin-dependent kinase II mediates simultaneous enhancement of gap-junctional conductance and glutamatergic transmission. Proc Natl Acad Sci U S A 95:13272-13277. CrossRef Medline

Quanhong Z, Ying X, Moxi C, Tao X, Jing W, Xin Z, Li W, Derong C, Xiaoli Z, Wei J (2012) Intrathecal PLC(beta3) oligodeoxynucleotides antisense potentiates acute morphine efficacy and attenuates chronic morphine tolerance. Brain Res 1472:38-44. CrossRef Medline

Ramírez OA, Couve A (2011) The endoplasmic reticulum and protein trafficking in dendrites and axons. Trends Cell Biol 21:219-227. CrossRef Medline

Randall LO, Selitto JJ (1957) A method for measurement of analgesic activity on inflamed tissue. Arch Int Pharmacodyn Ther 111:409-419. Medline

Reichling DB, Levine JD (2009) Critical role of nociceptor plasticity in chronic pain. Trends Neurosci 32:611-618. CrossRef Medline

Richter JD (2007) CPEB: a life in translation. Trends Biochem Sci 32:279285. CrossRef Medline

Ryu SY, Beutner G, Kinnally KW, Dirksen RT, Sheu SS (2011) Single channel characterization of the mitochondrial ryanodine receptor in heart mitoplasts. J Biol Chem 286:21324-21329. CrossRef Medline

Sattelle DB, Cordova D, Cheek TR (2008) Insect ryanodine receptors: molecular targets for novel pest control chemicals. Invert Neurosci 8:107119. CrossRef Medline

Shakiryanova D, Klose MK, Zhou Y, Gu T, Deitcher DL, Atwood HL, Hewes RS, Levitan ES (2007) Presynaptic ryanodine receptor-activated calmodulin kinase II increases vesicle mobility and potentiates neuropeptide release. J Neurosci 27:7799-7806. CrossRef Medline

Shakiryanova D, Morimoto T, Zhou C, Chouhan AK, Sigrist SJ, Nose A, Macleod GT, Deitcher DL, Levitan ES (2011) Differential control of presynaptic CaMKII activation and translocation to active zones. J Neurosci 31:9093-9100. CrossRef Medline

Song MJ, Wang YQ, Wu GC (2009) Additive anti-hyperalgesia of electroacupuncture and intrathecal antisense oligodeoxynucleotide to interleukin-1 receptor type I on carrageenan-induced inflammatory pain in rats. Brain Res Bull 78:335-341. CrossRef Medline

Stutzmann GE, Mattson MP (2011) Endoplasmic reticulum $\mathrm{Ca}(2+)$ han- dling in excitable cells in health and disease. Pharmacol Rev 63:700-727. CrossRef Medline

Su L, Wang C, Yu YH, Ren YY, Xie KL, Wang GL (2011) Role of TRPM8 in dorsal root ganglion in nerve injury-induced chronic pain. BMC Neurosci 12:120. CrossRef Medline

Sun JL, Xiao C, Lu B, Zhang J, Yuan XZ, Chen W, Yu LN, Zhang FJ, Chen G, Yan M (2013) CX3CL1/CX3CR1 regulates nerve injury-induced pain hypersensitivity through the ERK5 signaling pathway. J Neurosci Res 91: 545-553. CrossRef Medline

Taiwo YO, Levine JD (1989) Prostaglandin effects after elimination of indirect hyperalgesic mechanisms in the skin of the rat. Brain Res 492:397399. CrossRef Medline

Taiwo YO, Coderre TJ, Levine JD (1989) The contribution of training to sensitivity in the nociceptive paw-withdrawal test. Brain Res 487:148 151. CrossRef Medline

Taiwo YO, Heller PH, Levine JD (1990) Characterization of distinct phospholipases mediating bradykinin and noradrenaline hyperalgesia. Neuroscience 39:523-531. CrossRef Medline

VanBerkum MF, Goodman CS (1995) Targeted disruption of $\mathrm{Ca}(2+)$ calmodulin signaling in Drosophila growth cones leads to stalls in axon extension and errors in axon guidance. Neuron 14:43-56. CrossRef Medline

Van Petegem F (2012) Ryanodine receptors: structure and function. J Biol Chem 287:31624-31632. CrossRef Medline

Villalba A, Coll O, Gebauer F (2011) Cytoplasmic polyadenylation and translational control. Curr Opin Genet Dev 21:452-457. CrossRef Medline

Witcher DR, Kovacs RJ, Schulman H, Cefali DC, Jones LR (1991) Unique phosphorylation site on the cardiac ryanodine receptor regulates calcium channel activity. J Biol Chem 266:11144-11152. Medline

Wong MY, Shakiryanova D, Levitan ES (2009) Presynaptic ryanodine receptor-CamKII signaling is required for activity-dependent capture of transiting vesicles. J Mol Neurosci 37:146-150. CrossRef Medline

Wu L, Wells D, Tay J, Mendis D, Abbott MA, Barnitt A, Quinlan E, Heynen A, Fallon JR, Richter JD (1998) CPEB-mediated cytoplasmic polyadenylation and the regulation of experience-dependent translation of alphaCaMKII mRNA at synapses. Neuron 21:1129-1139. CrossRef Medline

Yamauchi T (2005) Neuronal Ca2+/calmodulin-dependent protein kinase II-discovery, progress in a quarter of a century, and perspective: implication for learning and memory. Biol Pharm Bull 28:1342-1354. CrossRef Medline

Yi M, Weaver D, Eisner V, Várnai P, Hunyady L, Ma J, Csordás G, Hajnóczky G (2012) Switch from ER-mitochondrial to SR-mitochondrial calcium coupling during muscle differentiation. Cell Calcium 52:355-365. CrossRef Medline

Zalk R, Lehnart SE, Marks AR (2007) Modulation of the ryanodine receptor and intracellular calcium. Annu Rev Biochem 76:367-385. CrossRef Medline 